\title{
Evaluation of the Biocompatibility and Osteoconduction of the Carbon Nanotube, Chitosan and Hydroxyapatite Nanocomposite with or without Mesenchymal Stem Cells as a Scaffold for Bone Regeneration in Rats
}

\author{
Geissiane M. Marcondes ${ }^{1, *}$, Nicole F. Paretsis ${ }^{1}$, Joice Fülber ${ }^{2}$, Pedro Enrique Navas-Suárez ${ }^{3}$ (D), \\ Claudia M. C. Mori ${ }^{3}{ }^{\mathbb{D}}$, Ana Maria G. Plepis ${ }^{4}$, Virginia C. A. Martins ${ }^{4}$, Denise T. Fantoni ${ }^{1}$ and \\ André L. V. Zoppa ${ }^{1}$ (i)
}

1 Department of Surgery, School of Veterinary Medicine and Animal Science, University of São Paulo (FMVZ-USP), Prof. Orlando Marques Paiva Avenue 87, Butantã, São Paulo 05508-270, SP, Brazil; nicoleparetsis@gmail.com (N.F.P.); dfantoni@usp.br (D.T.F.); alzoppa@usp.br (A.L.V.Z.)

2 Laboratory of Cell Culture and Regenerative Therapy, Department of Internal Medicine, School of Veterinary Medicine and Animal Science, University of São Paulo (FMVZ-USP), Avenida Prof. Orlando Marques Paiva Avenue 87, Butantã, São Paulo 05508-270, SP, Brazil; jfulber@usp.br

Citation: Marcondes, G.M.; Paretsis, N.F.; Fülber, J.; Navas-Suárez, P.E.; Mori, C.M.C.; Plepis, A.M.G.; Martins, V.C.A.; Fantoni, D.T.; Zoppa, A.L.V. Evaluation of the Biocompatibility and Osteoconduction of the Carbon Nanotube, Chitosan and

Hydroxyapatite Nanocomposite with or without Mesenchymal Stem Cells as a Scaffold for Bone Regeneration in Rats. Osteology 2021, 1, 118-131. https://doi.org/10.3390/ osteology1030013

Academic Editor: Rossella Bedini

Received: 20 May 2021

Accepted: 22 July 2021

Published: 27 July 2021

Publisher's Note: MDPI stays neutral with regard to jurisdictional claims in published maps and institutional affiliations.

Copyright: (C) 2021 by the authors Licensee MDPI, Basel, Switzerland. This article is an open access article distributed under the terms and conditions of the Creative Commons Attribution (CC BY) license (https:/ / creativecommons.org/licenses/by/ $4.0 /)$.
3 Department of Pathology, School of Veterinary Medicine and Animal Science, University of São Paulo (FMVZ-USP), Prof. Orlando Marques Paiva Avenue 87, Butantã, São Paulo 05508-270, SP, Brazil; pnavas@usp.br (P.E.N.-S.); claudiam@usp.br (C.M.C.M.)

4 Laboratory of Biopolymers and Biomaterials, Department of Chemistry and Molecular Physics, Institute of Chemistry of São Carlos, University of São Paulo (IQSC-USP), Trabalhador São-Carlense Avenue 400, Parque Arnold Schmidt, São Carlos 13566-590, SP, Brazil; amplepis@iqsc.usp.br (A.M.G.P.); virginia@iqsc.usp.br (V.C.A.M.)

* Correspondence: gemmarcondes@gmail.com

\begin{abstract}
Background: Bone substitutes have been developed to assist bone regeneration in orthopedic surgeries. Mesenchymal stem cells can be added to these biomaterials to enhance bone regeneration. This study aimed to evaluate the biocompatibility and osteoconduction of a carbon nanotube, chitosan, and hydroxyapatite nanocomposite $(\mathrm{CNCHN})$ that had either been enriched or not enriched with sheep bone marrow mesenchymal stem cells (BM-MSCs) in rats. Methods: A total of sixty rats were divided into groups, and an implant with or without BM-MSCs was performed subcutaneously in 20 animals (euthanized after 7 and 30 days), comparing them to 10 control animals, and in the calvaria of 20 animals (euthanized after 20 and 60 days), comparing to with 10 control animals. Subcutaneous and calvaria histologies were performed after euthanasia. Results: The subcutaneous tissue showed that CNCHN did not prompt an exacerbated inflammatory response or signs of necrosis. The histomorphological analysis by the calvaria score of the rats showed that the control group had lower scores at 20 and 60 days for bone neoformation, relative to the CNCHN groups, which showed no significant statistical differences, suggesting that the nanocomposite assisted in the regenerative process of defects in the calvaria, but with no repair potentiation when using BM-MSCs. Conclusion: $\mathrm{CNCHN}$ has biocompatibility and osteoconductive potential, showing promising results in bone defects.
\end{abstract}

Keywords: bone tissue engineering; biomaterials; animal fracture; bone repair

\section{Introduction}

Biomaterials have been developed to maximize bone regeneration, supporting the treatment of fractures with significant tissue loss [1-3]. Hydroxyapatite is the main inorganic constituent of bone and has been widely used to prepare scaffolds to aid in bone regeneration. Chitosan is one of the most highly used polysaccharide-based biopolymers to develop scaffolds because of its proper chemical structure, biocompatibility, and biodegradability [4]. Composites with natural constituents such as chitosan and hydroxyapatite have shown satisfactory 
results because they have a chemical structure similar to that of bone tissue components [2,5-7]. The combination of these constituents, in addition to increasing mechanical strength, improves the osteogenic property of the composites [4]. Carbon nanotubes are cylindrical molecules made of folded two-dimensional graphene sheets [8] with unique structural and physicochemical properties and high electrical conductivity [9]. They can assist in improving the structural strength and biomechanical resistance of bone substitutes $[10,11]$. Additionally, carbon nanotube scaffolds can increase the bone matrix production of bone-forming cells in vivo as well as accelerate the adhesion and osteogenic differentiation of MSCs in vitro [9].

In the last decade, the number of studies in the field of tissue engineering with the development of materials enriched with mesenchymal stem cells has been gradually increasing $[12,13]$. Bone marrow mesenchymal stem cells have osteogenic potential and can promote the enhancement of bone growth when incorporated into ceramics or polymers, resulting in scaffolds depending on the way they are grown with these biomaterials [13-17].

The scaffolds for bone regeneration under clinical conditions must be subjected to in vivo evaluations in laboratory animals before being used in the species of interest, respecting current precepts and standards related to animal experimentation $[16,18,19]$. The implantation of biomaterials in the subcutaneous tissue to evaluate biocompatibility and defects in rat calvaria for determining osteoconduction consists of experimental models that have been widely used for studies in bone bioengineering [20-23].

Histological evaluations after a period of bone substitute implantation allow for the evaluation of the characteristics of the inflammatory response, integration with adjacent tissues, biodegradation, and the potential for bone regeneration [18,24-26]. The nanocomposite used in this experiment has not been previously evaluated in vivo, but an absence of cytotoxicity was observed in an in vitro study [27]. The mesenchymal stem cells were derived from sheep bone marrow, a species widely used for studies in orthopedics $[13,15,28]$. This study aimed to evaluate the biocompatibility and osteoconductive potential of the carbon nanotube, chitosan, and hydroxyapatite nanocomposite ( $\mathrm{CNCHN})$ that had either been enriched or not enriched with sheep bone marrow mesenchymal stem cells (BMMSCs) in subcutaneous and rat calvaria through qualitative and quantitative histological evaluations at different times after implantation, comparing them to the control. Therefore, due to the properties that make up the composite, this experiment hypothesizes that this bone substitute has biocompatibility and osteoconductive potential when applied to the tissues of laboratory animals and that BM-MSCs can enhance the bone repair process.

\section{Materials and Methods}

\subsection{Carbon Nanotube, Chitosan, and Hydroxyapatite Nanocomposite (CNCHN)}

The nanocomposite was produced by the Institute of Chemistry of São Carlos of the University of São Paulo and the entire process of production, characterization, and evaluation of in vitro cytotoxicity was previously described by the research group [27]. The composites consisted of $10 \mathrm{~mm}$ discs for subcutaneous implantation and $7 \mathrm{~mm}$ discs for rat calvaria implantation, which had been previously sterilized in ethylene oxide for use at the time of surgery (Figure 1).

\subsection{Cultivation and Differentiation of Sheep Bone Marrow Mesenchymal Stem Cells (BM-MSCs)}

BM-MSCs were obtained from the collection of the iliac crest from 4-month-old donor young sheep following the method previously described in [29]. The entire process of cultivation, differentiation, and preparation of BM-MSCs was carried out at the Laboratory of Cell Culture and Regenerative Medicine of the Department of Internal Medicine at FMVZ-USP, according to previously described protocols [30,31]. The cell viability at the application time was measured by the trypan blue $(0.2 \%)$ exclusion, performed under an optical microscope, based on the count of dead cells stained in blue and intact unstained cells. BM-MSCs were characterized according to their multipotent capacity through osteogenic, chondrogenic, and adipogenic differentiation from their induction in these strains with a commercial inducing 
medium (StemPro osteogenesis, chondrogenesis and adipogenesis kit, GIBCO Thermo Fisher Scientific ${ }^{\circledR}$, Carlsbad, CA, USA) as previously described [32].

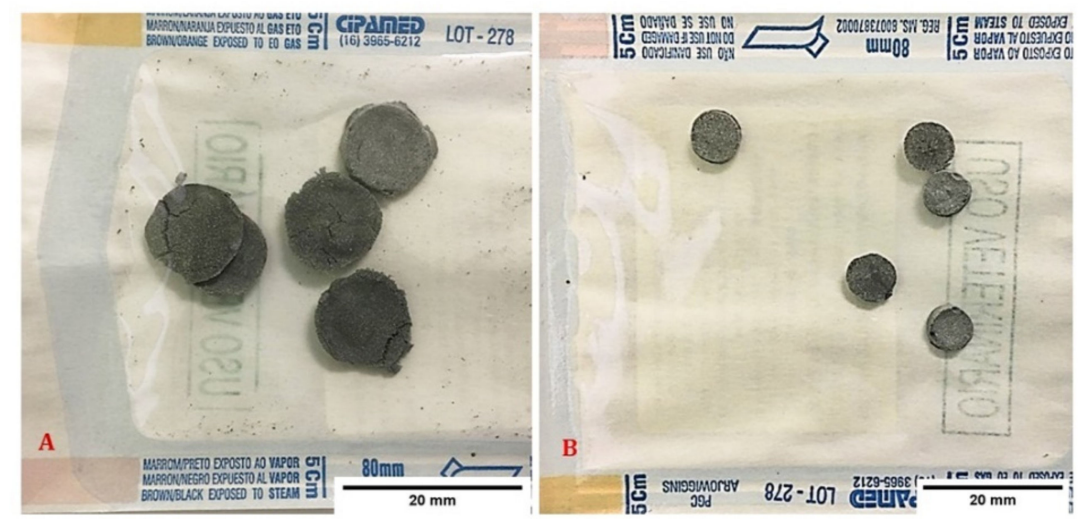

Figure 1. (A) $\mathrm{CNCHN}$ discs used for subcutaneous implantation. (B) CNCHN discs used for calvaria implantation.

\subsection{Experimental Design}

Sixty male heterogeneous rats (Rattus norvegicus albinus), weighing 300-400 g and approximately 120 days old, were used. The animals came from the Vivarium of the Department of Pathology at FMVZ-USP and were maintained in the same place throughout the research period, being housed in a room with central air conditioning at a temperature of $22 \pm 2{ }^{\circ} \mathrm{C}$ inside open polypropylene cages measuring $41 \times 35 \times 16 \mathrm{~cm}$, lined with granulated corn cob bedding changed every 7 days. They were subjected to a $12 / 12 \mathrm{~h}$ day/night cycle and fed rodent food (Nuvilab-CR1, Quimtia ${ }^{\circledR}$, Colombo, Brazil) and water ad libitum. The 60 animals were divided into groups, with subcutaneous surgery performed on 30 animals and calvaria surgery performed in the other 30 animals (Figures 2 and 3). This research was approved by the Ethics Committee on the Use of Animals of the School of Veterinary Medicine and Animal Science (FMVZ) of the University of São Paulo (USP), under protocol number 7100150715.

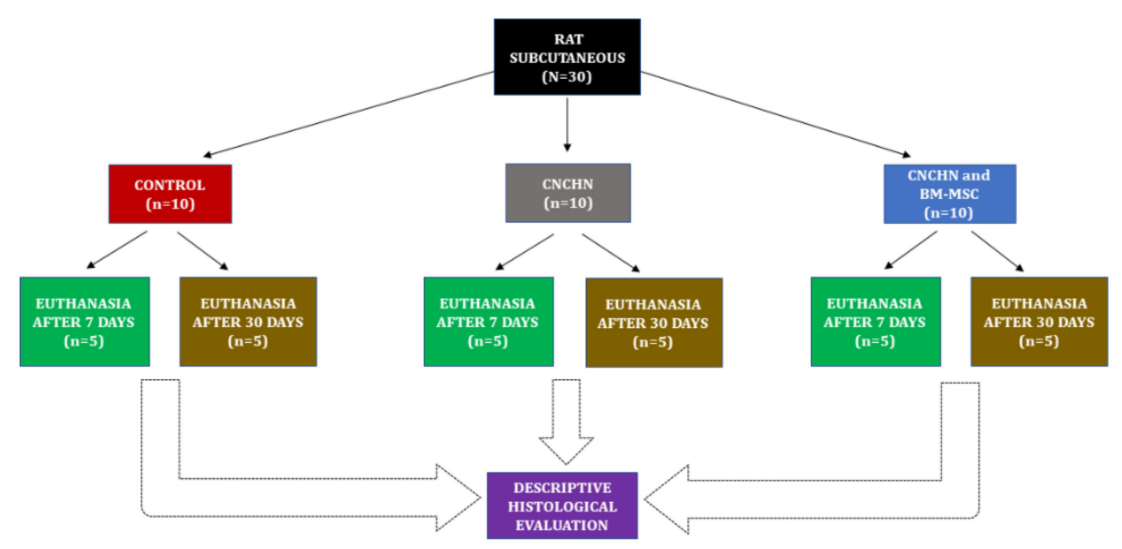

Figure 2. Schematic representation of the experimental design for the subcutaneous study in rats. 


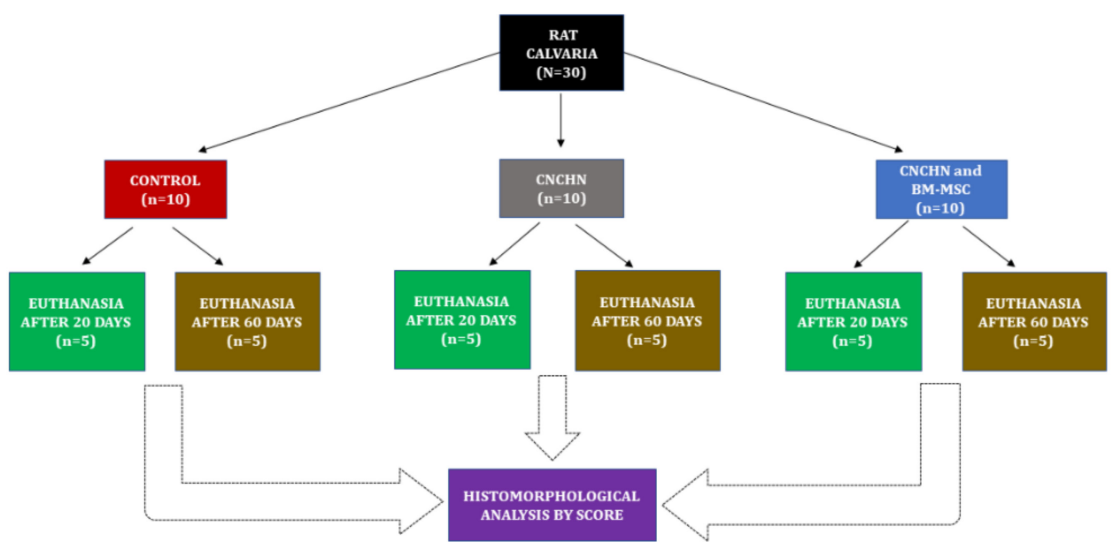

Figure 3. Schematic representation of the experimental design for the calvaria study in rats.

\subsection{Surgical Procedures}

Morphine sulfate $(10 \mathrm{mg} / \mathrm{kg}$, IP) was used as an anesthetic protocol for surgical procedures subcutaneously and in the calvaria. The induction was performed after $10 \mathrm{~min}$ using $4 \%$ isoflurane in a plastic box and maintenance with $1.5 \%$ isoflurane via mask. Antibiotic therapy was performed with gentamicin sulfate $(5 \mathrm{mg} / \mathrm{kg}, \mathrm{SC})$ during the transoperative period. The preparation of the subcutaneous surgical site consisted of dorsum trichotomy and subsequent antisepsis. The animals were positioned on a bench used for experimental surgeries, heated with a thermal mattress at $37^{\circ} \mathrm{C}$ to maintain body temperature. An incision of approximately $15 \mathrm{~mm}$ in length was made in the dorsum region, with subsequent blunt divulsion in the subcutaneous tissue. Animals from the control groups did not receive composite implants and, therefore, the skin was sutured with mononylon 3-0 thread after the subcutaneous divulsion. In the others, the nanocomposite discs were implanted in the subcutaneous space, and, in some groups, BM-MSCs at the concentration of $0.5 \times 10^{6}$ viable cells in the third passage (P3) were resuspended in $0.2 \mathrm{~mL}$ saline solution and instilled in the composite during the surgery, which ended with skin suturing (Figure 4).
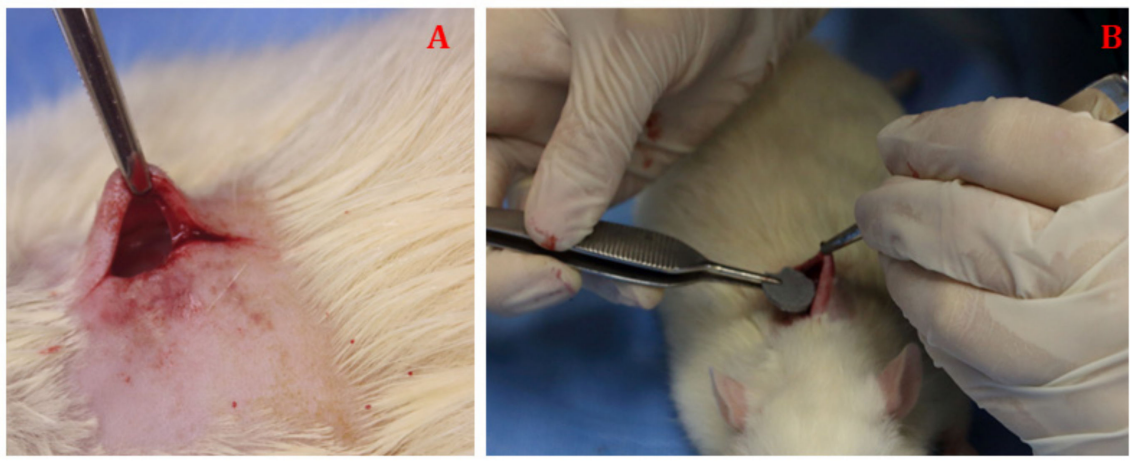

Figure 4. (A) Dorsum region after subcutaneous tissue divulsion. (B) CNCHN implant. Schematic representation of the experimental design for study in rat calvaria.

Trichotomy and wide antisepsis of the parietal bone region were performed for the surgical procedure in the calvaria. A rectilinear incision of about $20 \mathrm{~mm}$ was made in the skin of the medial region of the skull, extending from the nasofrontal region to the occipital protuberance. After the skin incision, the subcutaneous tissue, the temporal muscle, and the periosteum were folded laterally for complete exposure of the parietal bone. After direct exposure of the calvaria to standardize the area to be manipulated, the left parietal bone was the site of choice to perform the bone defect

A $7 \mathrm{~mm}$ bone defect was made using a steel trephine drill with a $5 \mathrm{~mm}$ internal diameter (INP ${ }^{\circledR}$, São Paulo, Brazil), adapted to the contra-angle in an implant motor 
(Driller ${ }^{\circledR}$, São Paulo, Brazil) under low rotation and constant irrigation with saline solution. After the removal of the circular fragment from the calvaria of the animals from the control group, the skin was sutured with mononylon 3-0 thread. In the others, nanocomposite discs were implanted in the calvaria failure, and BM-MSCs were instilled in pre-determined groups, as previously described (Figure 5).

\subsection{Post-Surgical and Euthanasia Procedures}

Postoperative analgesia was performed with tramadol ( $5 \mathrm{mg} / \mathrm{kg}, \mathrm{SC})$ for 2 days after surgical procedures. Two animals remained in each cage, being observed daily regarding water and feed intake and surgical wound healing. After the end of the evaluation times within each group, the animals were euthanized using a dose of barbiturate with sodium thiopental $(150 \mathrm{mg} / \mathrm{kg}, \mathrm{IP})$ and potassium chloride intraperitoneally until cardiorespiratory arrest.
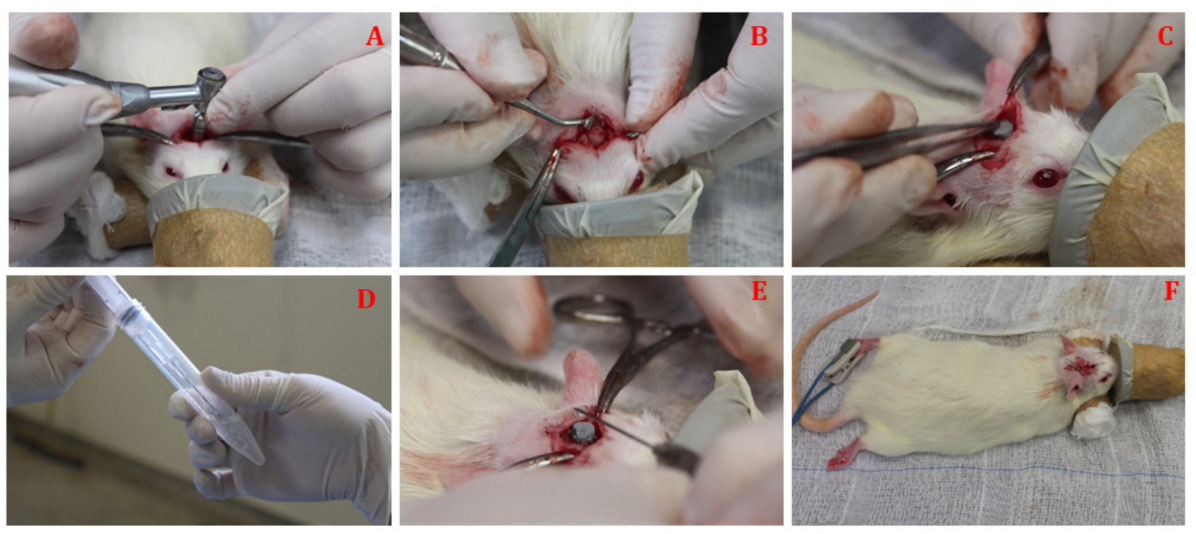

Figure 5. (A) Performing ostectomy with a trephine drill. (B) Removal of the bone fragment from the calvaria. (C) CNCHN implant. (D) Aspiration of BM-MSCs in saline solution. (E) Instillation of BM-MSCs at the implant site. (F) Completion of the surgical procedure.

\subsection{Preparation of Specimens for Histological Evaluation}

The dorsum or the calvaria regions were dissected after euthanasia to collect material, and the specimens were fixed in $10 \%$ formaldehyde for $24 \mathrm{~h}$. Subcutaneous implantation specimens were washed with running water after $24 \mathrm{~h}$ of fixation, packed in unit cassettes, and placed in an automated histological processor. Subsequently, the material was soaked in liquid paraffin to obtain blocks for histological cutting. The paraffin blocks were identified and placed in an automatic microtome to allow cuts that were 5 micrometers thick. After the slides were completely dried in an oven at $60^{\circ} \mathrm{C}$ for two hours, the sections were stained with hematoxylin-eosin (HE). The analysis was performed using a light optical microscope, where the images were acquired and then digitalized using a camera for evaluation. A descriptive analysis of the images was performed by a pathologist, prioritizing characteristics of the inflammatory infiltrate, vascularization, fibrous capsule, and residual material. The calvaria implantation specimens were subjected to a decalcification process in $10 \%$ formic acid for $24 \mathrm{~h}$ after fixation. The fragments were washed and dehydrated in successive baths of increasing ethanol concentrations (70-100\%) and were diaphanized in xylol. A total of three 2-h paraffin baths preceded block inclusion in the same material. Longitudinal cuts of 5 micrometers in thickness were obtained using a manual microtome. The sections, once collected on slides, were stained with hematoxylin-eosin (HE). An analysis was performed using an optical light microscope with subsequent digitalization of the sections using a camera, and the histomorphological aspects of bone repair in the calvaria specimens were evaluated by a pathologist in an armored manner for the groups, considering the presence of repair characteristics, such as inflammatory infiltrate, granulation tissue, necrosis, osteoclasts, neoformed vessels, and bone neoformation. The histopathological score was based on an arbitrary scale classified from zero to four [33], which represents: 0 , absent; 1 , discreet (up to $25 \%$ of the field showing the tissue element); 2 , discrete to 
moderate (from $25 \%$ to $50 \%$ of the field); 3 , moderate to intense (from $50 \%$ to $75 \%$ of the field), and 4 , intense (more than $75 \%$ of the field).

\subsection{Statistical Analysis}

The variables of the calvaria histomorphological data were described by the median and interquartile ranges ( 25 and 75 percentiles) and compared between groups using the Kruskal-Wallis test. The variables were ordered by rank, which were compared using Tukey's post hoc test to detect differences. A 5\% significance level was considered for the established comparisons.

\section{Results}

3.1. Cultivation and Differentiation of Sheep Bone Marrow Mesenchymal Stem Cells (BM-MSCs)

BM-MSCs could adhere to plastic, showed growth in monolayer, were morphologically similar to fibroblasts, and maintained their morphology during cell expansion until at least the third passage, which was used in the study. Osteogenic differentiation was confirmed after 21 days using alizarin red staining, showing a calcium matrix. Chondrogenic differentiation was confirmed after making a histological slide stained in toluidine blue and alcian blue. Moreover, the adipogenic capacity was confirmed after oil red $\mathrm{O}$ staining, which showed lipid droplets in the cytoplasm of cells. The cell population that had been used as a control (non-differentiated) showed no positive staining for the strains (Figure 6).

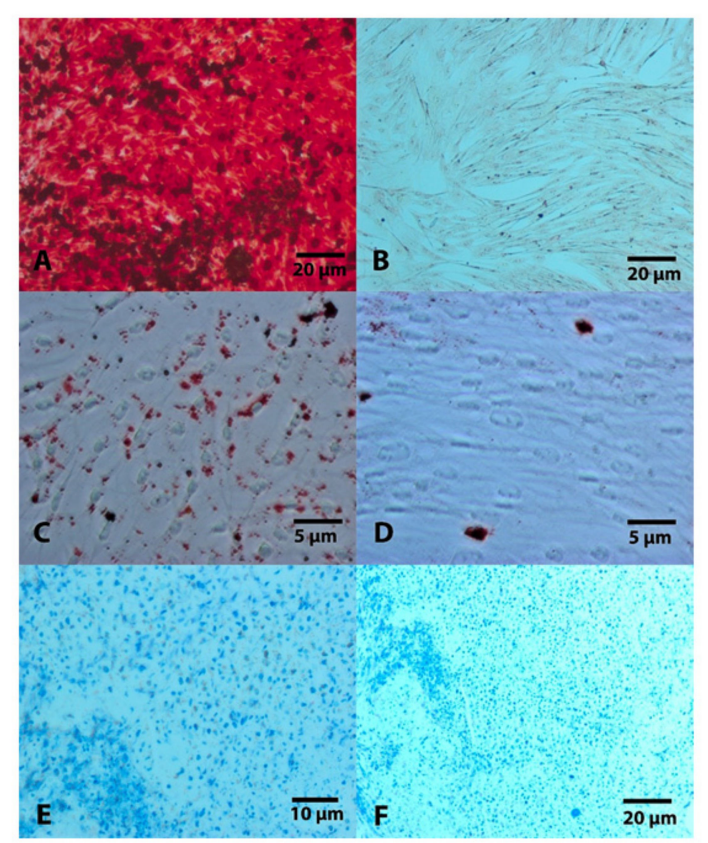

Figure 6. Differentiation of MSCs from sheep bone marrow into mesenchymal lineages during P3. (A): MSCs stained with alizarin red showing matrix calcium formation, confirming the osteogenic lineage (red); (B): MSCs control stained with alizarin red; (C): MSCs stained with oil red O showing intracytoplasmic lipid droplets, confirming the adipogenic lineage; (D): MSCs control stained with oil red O; (E,F) MSCs after chondrogenic differentiation stained with toluidine blue showing hyaline matrix (blue).

\subsection{Animals}

The anesthetic protocols showed satisfactory results since no complications were observed during surgeries. Both subcutaneous and calvaria surgical techniques allowed for easy access and enabled the standardization of the experimental model. The calvaria remained stable during the trephine drilling used to gain access to it despite not using an apparatus to fix the head (stereotaxic). The animal handling during postoperative management occurred without complications. Only three animals that underwent the 
ostectomy procedure on the calvaria showed signs of discomfort, requiring the use of rescue analgesic medication. All animals were maintained with skin sutures until the time of euthanasia without any surgical wound complications.

\subsection{Descriptive Histology of the Subcutaneous Tissue}

The microscopic findings in the subcutaneous tissue of the different groups and times are shown in Table 1 and Figure 7.

Table 1. Microscopic findings.

\begin{tabular}{ll}
\hline Group & Histopathologic Findings \\
\hline & The represented fragments have a focal ulcerated area; the dermis and hypodermis have a mild to \\
moderate inflammatory infiltrate that is predominantly histiocytic/lymphocytic, with few \\
multinucleated giant cells phagocyting structures of a circular morphology, presenting a refringent \\
external layer and an eosinophilic center (500 micra, compatible with suture). In one case, the foreign \\
body
\end{tabular}

The represented fragments have a mineralized matrix structure $(\mathrm{CNCHN})$ measuring approximately $1.5 \times 0.3 \mathrm{~cm}$ in the hypodermis; a mild degree of the mononuclear (lymphocytic-plasmacytic and

$\mathrm{CNCHN}$ histiocytic) inflammatory response as well as mild areas of hemorrhage is observed inside the

7 days structure. The structure is surrounded by a matrix of fibrous tissue and a mild-moderate mononuclear (lymphocytic-plasmacytic and histiocytic) inflammatory infiltrate. Minimal multifocal angiogenesis is observed. No noticeable changes are observed in the epidermis or in the internal muscular layers (Figure 7B)

The represented fragments have a mineralized matrix structure measuring approximately $1.5 \times 0.3 \mathrm{~cm}$ in the hypodermis; a moderate mononuclear (lymphocytic-plasmacytic and histiocytic) inflammatory response as well as moderate areas of hemorrhage is observed inside the structure;

CNCHN and BM-MSCs 7 days immature hematopoietic tissue is observed inside the structure (stem cells). The structure is surrounded by a matrix of fibrous tissue and a moderate mononuclear (lymphocytic-plasmacytic and histiocytic) inflammatory infiltrate. However, some multinucleated giant cells of foreign body type are observed. Moderate to marked areas of hemorrhage and angiogenesis are observed. No noticeable changes are observed in the epidermis or in the internal muscular layers (Figure 7C)

Control

30 days The represented fragments have no noteworthy changes (Figure 7D)

The represented fragments have a mineralized matrix structure measuring approximately $1.5 \times 0.3 \mathrm{~cm}$ in the hypodermis; a mild mononuclear (lymphocytic-plasmacytic and histiocytic) inflammatory response with few multinucleated giant cells is observed inside the structure. The $\mathrm{CNCHN}$ structure is surrounded by a thin matrix of fibrous tissue and a minimal mononuclear 30 days (lymphocytic-plasmacytic and histiocytic) inflammatory infiltrate as well as minimal areas of hemorrhage. CNCHN is observed in the lumen inside the blood vessels of the peripheral region. Multiple areas of histiocytic infiltrate with the formation of multinucleated giant cells with intracytoplasmic brown pigment are observed in the dermis and hypodermis (Figure 7E)

The represented fragments have a structure of the mineralized matrix measuring approximately $1.5 \times 0.3 \mathrm{~cm}$ in the hypodermis; a moderate mononuclear (lymphocytic-plasmacytic and histiocytic)

CNCHN and BM-MSCs 30 days inflammatory response with multinucleated giant cells (foreign body type) is observed inside the structure. There are marked areas of hemorrhage. The structure is surrounded by a thin matrix of fibrous tissue and a mild mononuclear (lymphocytic-plasmacytic and histiocytic) inflammatory infiltrate. No noticeable changes are observed in the epidermis or in the internal muscle layer (Figure 7F) 


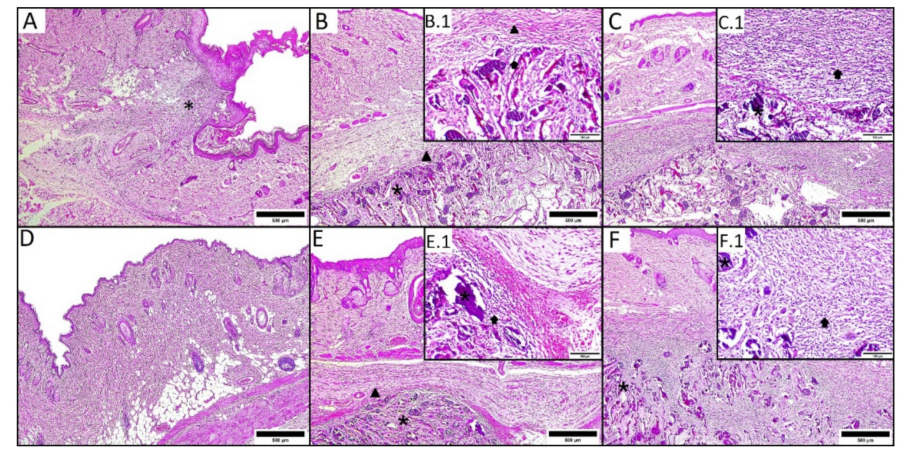

Figure 7. Histological sections of skin and subcutaneous tissue of rats with and without biomaterial implant. (A) Note an ulcer: the dermis and hypodermis show a slight to moderate inflammatory infiltrate (black asterisk). HE, obj.4x. (B) A mineral matrix structure surrounded (black asterisk) by fibrous tissue (black triangle) and a mononuclear inflammatory infiltrate (black arrow) are observed in the hypodermis (B = HE, scale-bar $=500 \mu \mathrm{m} / / \mathrm{B} .1=\mathrm{HE}$, scale-bar $=100 \mu \mathrm{m})$. $(C)$ The structure of the mineral matrix (black asterisk) is observed in the hypodermis; a moderate mononuclear inflammatory (black arrow) response $(\mathrm{C}=\mathrm{HE}$, scale-bar $=500 \mu \mathrm{m} / \mathrm{C} .1=\mathrm{HE}$, scale-bar $=100 \mu \mathrm{m})$ is observed inside the structure. (D) Fragment without any noteworthy changes. HE, obj.4x. (E) A mineral matrix structure (black asterisk) is observed in the hypodermis; a mild mononuclear inflammatory infiltrate with few multinucleated giant cells is found inside the structure. The structure is surrounded by a thin matrix of fibrous tissue (black triangle) and a minimal mononuclear inflammatory (black arrow) infiltrate $(\mathrm{E}=\mathrm{HE}$, scale-bar $=500 \mu \mathrm{m} / \mathrm{E} .1=\mathrm{HE}$, scale-bar $=100 \mu \mathrm{m}) .(\mathbf{F})$ A mineral matrix (black asterisk) is observed in the hypodermis; inside, there is a moderate mononuclear inflammatory (black arrow) infiltrate with multinucleated giant cells $(\mathrm{F}=\mathrm{HE}$, scale-bar $=500 \mu \mathrm{m} / \mathrm{F} .1=\mathrm{HE}$, scale-bar $=100 \mu \mathrm{m})$.

\subsection{Histomorphological Analysis of Calvaria}

The control group presented lower values regarding the score for inflammatory infiltrate at 20 days than for the other groups $(p=0.005)$. The score for granulation tissue and bone neoformation in the control group was lower than in the other groups, both at 20 and 60 days. The histological score for osteoclasts was lower for the control group at 20 and 60 days ( $p=0.003$ and $p=0.015$, respectively) than for the other groups (Tables 2 and 3 ).

Table 2. Comparison of the histomorphological analysis in the calvaria between groups of rats at 20 days after ostectomy.

\begin{tabular}{|c|c|c|c|c|c|c|c|c|c|c|}
\hline & \multicolumn{3}{|c|}{ Control } & \multicolumn{3}{|c|}{ CNCHN } & \multicolumn{3}{|c|}{$\mathrm{CNCHN}$ and BM-MSC } & \multirow[b]{3}{*}{$p$} \\
\hline & \multirow[b]{2}{*}{ Median } & \multicolumn{2}{|c|}{ Percentile } & \multirow[b]{2}{*}{ Median } & \multicolumn{2}{|c|}{ Percentile } & \multirow{2}{*}{ Median } & \multicolumn{2}{|c|}{ Percentile } & \\
\hline & & 25 & 75 & & 25 & 75 & & 25 & 75 & \\
\hline Inflammatory infiltrate & $0.0^{\mathrm{a}}$ & 0.0 & 1.5 & $1.0^{\mathrm{a}}$ & 1.0 & 1.0 & $3.0^{b}$ & 3.0 & 4.0 & 0.005 \\
\hline Granulation tissue & $3.0^{\mathrm{a}}$ & 3.0 & 3.0 & $4.0^{\mathrm{b}}$ & 4.0 & 4.0 & $4.0^{b}$ & 3.5 & 4.0 & 0.004 \\
\hline Necrosis & 0.0 & 0.0 & 0.0 & 0.0 & 0.0 & 0.0 & 0.0 & 0.0 & 0.0 & 0.999 \\
\hline Osteoclasts & $1.0^{\mathrm{a}}$ & 0.0 & 1.5 & $3.0^{b}$ & 3.0 & 3.0 & $4.0^{\mathrm{b}}$ & 3.0 & 4.0 & 0.003 \\
\hline Neoformed vessels & $1.0^{\mathrm{a}}$ & 1.0 & 2.5 & $3.0^{\mathrm{a}, \mathrm{b}}$ & 3.0 & 3.0 & $4.0^{\mathrm{b}}$ & 2.5 & 4.0 & 0.021 \\
\hline Bone neoformation & $2.0^{\mathrm{a}}$ & 1.5 & 2.0 & $3.0^{b}$ & 3.0 & 3.0 & $3.0^{\mathrm{b}}$ & 2.0 & 3.5 & 0.021 \\
\hline
\end{tabular}

Means followed by different letters $\left.{ }^{(a, b}\right)$ represent statistical differences from the Kruskal-Wallis test. 
Table 3. Comparison of the histomorphological analysis between groups of rat calvaria at 60 days after ostectomy.

\begin{tabular}{|c|c|c|c|c|c|c|c|c|c|c|}
\hline & \multicolumn{3}{|c|}{ Control } & \multicolumn{3}{|c|}{ CNCHN } & \multicolumn{3}{|c|}{ CNCHN and BM-MSC } & \multirow[b]{3}{*}{$p$} \\
\hline & \multirow[b]{2}{*}{ Median } & \multicolumn{2}{|c|}{ Percentile } & \multirow[b]{2}{*}{ Median } & \multicolumn{2}{|c|}{ Percentile } & \multirow[b]{2}{*}{ Median } & \multicolumn{2}{|c|}{ Percentile } & \\
\hline & & 25 & 75 & & 25 & 75 & & 25 & 75 & \\
\hline Inflammatory infiltrate & 0.0 & 0.0 & 1.0 & 0.0 & 0.0 & 1.5 & 1.0 & 1.0 & 1.0 & 0.212 \\
\hline Granulation tissue & $2.0^{\mathrm{a}}$ & 1.5 & 2.0 & $3.0^{b}$ & 3.0 & 3.0 & $3.0^{b}$ & 3.0 & 3.0 & 0.001 \\
\hline Necrosis & 0.0 & 0.0 & 0.0 & 0.0 & 0.0 & 0.0 & 0.0 & 0.0 & 0.0 & 0.999 \\
\hline Osteoclasts & $0.0^{\mathrm{a}}$ & 0.0 & 1.0 & $2.0^{\mathrm{b}}$ & 1.0 & 2.0 & $1.0^{\mathrm{a}, \mathrm{b}}$ & 1.0 & 1.0 & 0.015 \\
\hline Neoformed vessels & $1.0^{\mathrm{a}}$ & 1.0 & 1.0 & $2.0^{b}$ & 1.0 & 2.0 & $1.0^{\mathrm{a}}$ & 1.0 & 1.0 & 0.030 \\
\hline Bone neoformation & $2.0^{\mathrm{a}}$ & 2.0 & 2.0 & $3.0^{b}$ & 3.0 & 3.0 & $3.0^{b}$ & 3.0 & 3.0 & 0.001 \\
\hline
\end{tabular}

Means followed by different letters $\left({ }^{a, b}\right)$ represent statistical differences from the Kruskal-Wallis test.

The presence of an inflammatory infiltrate with a predominance of mononuclear cells was observed. Osteoclasts were easily observed to be concentrated in the repair area, allowing the visualization of the neoformed vessels that were distributed among the granulation tissue (Figure 8).

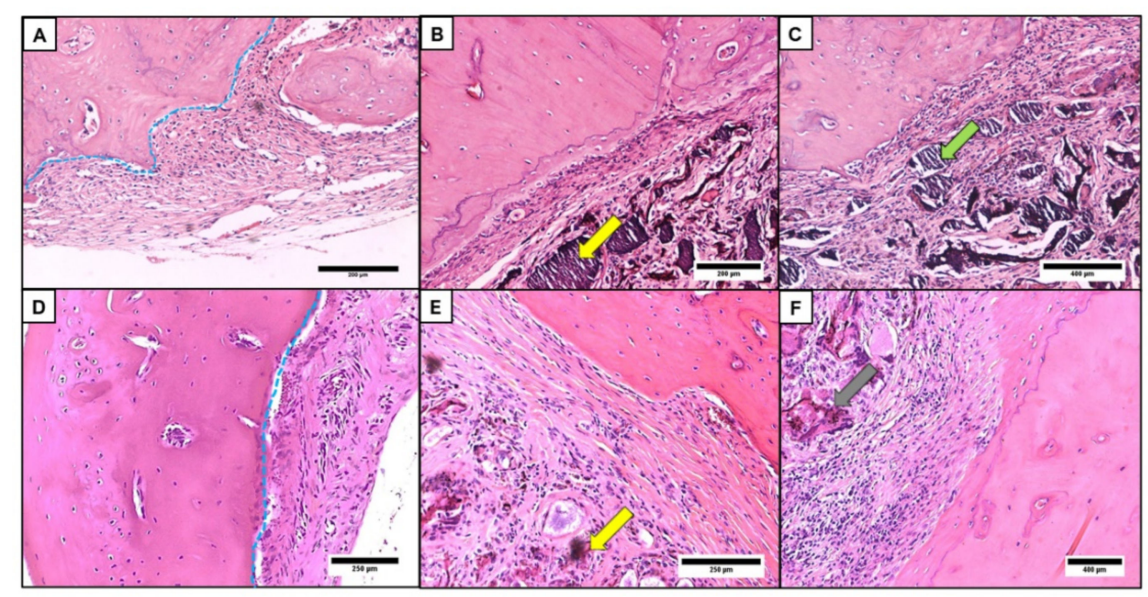

Figure 8. Histological sections of rat calvaria after ostectomy with and without biomaterial implant (HE, obj.10×). (A) Control at 20 days: moderate number of neoformed vessels and bundles of collagen fibers. The pre-existing bone tissue is represented above the blue dotted line and the neoformed tissue is below. (B) $\mathrm{CNCHN}$ at 20 days: discrete inflammatory infiltrate with a predominance of mononuclear cells and scarcity of neoformed vessels. The yellow arrow indicates remnants of $\mathrm{CNCHN}$ interspersed with the neoformed tissue. (C) CNCHN and BM-MSCs at 20 days: moderate inflammatory infiltrate with a predominance of mononuclear cells and presence of neoformed vessels. The green arrow indicates remnants of $\mathrm{CNCHN}$ and BM-MSC. (D) Control at 60 days: pre-existing bone tissue is to the left of the blue dotted line, while the neoformed bone tissue is on the right, showing a moderate number of bundles of collagen fibers. (E) CNCHN at 60 days: shortage of neoformed vessels with the presence of a large number of bundles of collagen fibers. The yellow arrow indicates remnants in CNCHN. (F) CNCHN and BM-MSCs at 60 days: discrete inflammatory infiltrate with a predominance of mononuclear cells and scarcity of neoformed vessels. The grey arrow indicates the presence of osteoclasts.

\section{Discussion}

Veterinary medicine has a great interest in the use of bone substitutes, supporting the treatment of fractures with bone tissue loss, especially in large animals [3]. However, there is a low availability of these biomaterials, as they need to be submitted to in vitro and in vivo evaluations before recommendation for clinical use and require proof of biocompatibility and osteoconduction $[5,7,25,34]$. The CNCHN used in the study is innovative and justifies the initial study in laboratory animals, as its constituents have important scaffold qualities, such as carbon nanotube chemical and resistance properties, porous structure, and chitosan biodegradation, in 
addition to biocompatibility and hydroxyapatite osteoconduction $[4,8,9,35,36]$. Their presentation as sterile discs facilitates their safe use in the transoperative moment, reflecting desirable characteristics when it comes to a bone substitute $[1,16]$.

This study followed methodologies widely used in studies on biocompatibility and bone regeneration with the use of biomaterials. The evaluation in the subcutaneous tissue started after two instances of $\mathrm{CNCHN}$ implantation to allow for the interpretation of the results that were related to acute and chronic tissue reaction $[20,23,26]$. Subsequently, we decided to perform a single $7 \mathrm{~mm}$ defect in the rat calvaria at the left antimere of the parietal bone, which facilitated both the surgical technique and the removal of specimens for microscopy. This methodology allowed for surgery standardization and minimized material losses for histological evaluations, in addition to being considered a critical defect size $[21,37]$. Rat calvaries were evaluated using histological methods after two instances of nanocomposite implantation in this study, allowing for the interpretation of the data related to the initial and long-term process of tissue repair, corroborating methodologies that have been established worldwide [38-40]. In addition, this study used a methodology based on the $3 \mathrm{R}$ principle for animal experimentation, selecting a minimum number of animals in each group, valuing analgesia and environmental comfort throughout the postoperative time and allowing for the replication of this methodology by other researchers [41,42].

The findings of the descriptive histology of the subcutaneous rat tissue after the composite implantation demonstrated, during the two evaluation moments, that $\mathrm{CNCHN}$ is easily infiltrated by inflammatory cells, with a predominance of mononuclear cells (lymphocytic-plasmacytic) with the presence of a fibrous capsule composed of collagen to circumscribe the material, an event that was expected under these implant conditions [20,43]. Angiogenesis could also be observed during this period in groups with $\mathrm{CNCHN}$, denoting preparation for the formation of granulation tissue in tissue repair processes occurring after biomaterial implantation [43]. These data agree with Amaral et al., who observed angiogenesis after the implantation of collagen, chitosan, and hydroxyapatite blankets in the subcutaneous layer of rats, considering it to be an important indication of biocompatibility. The absence of polymorphonuclear cells and/or signs suggestive of tissue necrosis adjacent to the composite reinforce biocompatibility $[23,43,44]$.

Multinucleated giant cells were observed in $\mathrm{CNCHN}$ and BM-MSC groups at both times, and in the CNCHN group only at 30 days, which suggests that, initially, xenogenic stem cells may have prompted an acute immune response, but without deleterious repercussions to the tissues, as these long-term cellular events were concentrated only in regions adjacent to the biomaterial [13]. Similarly, Sheik et al. [45] observed that multinucleated giant cells surrounding a composite demonstrate signs of phagocytic activity, which is important to confirm that it is being bioabsorbed. However, some composite remnants could be clearly observed at 30 days, demonstrating that it was not fully reabsorbed but that the slower resorption could be advantageous in the material for use in bone regeneration, given that its physical structure functions as a scaffold, directing bone growth as it is absorbed [11].

We opted for histomorphological analysis by scoring the calvaria repair process after ostectomy to obtain semi-quantitative data in the short and long term, corroborating established methodologies [33,37]. Inflammatory infiltrate at higher scores was initially observed in groups with CNCHN and BM-MSCs, which may be related to the fact that xenogenic cells trigger an acute inflammatory response, which has not been maintained over time [14]. The used BM-MSCs may have expressed their immunological regulatory properties in the long term, even in different species, although they acted with varied and not fully clarified mechanisms regardless of the main histocompatibility complex (MHC) [13]. Necrosis was not observed in any of the groups or evaluation times, suggesting the biocompatibility of CNCHN with the bone tissue [2,18,25]. Osteoclasts stimulated partial composite resorption, stimulating the initial stages of bone regeneration, indicating that the repair tissue is organized as it synchronously biodegrades $[1,6,35]$. Higher scores for granulation tissue at both evaluation times for the treated groups show that it was 
the basis for bone neoformation, behaving similarly compared to the control group and suggesting that this composite had osteoconductive potential, as it has chemical and structural components that stimulate the bone regenerative process [2,17].

Similar histomorphological scores for bone neoformation in groups with BM-MSCs and only $\mathrm{CNCHN}$ refute the hypothesis that stem cells would enhance the bone regenerative process. On the contrary, Blanco et al. used human stem cells in rat femur condyle defects along with biomaterial based on triphosphate granules and observed relative bone regeneration superiority in the group with cell therapy associated with the material. The use of sheep BM-MSCs applied to rats is justified in this study, as the objective was to use the composite with stem cells in large animal species in the future. Therefore, the translation of these results is valid, considering the extensive research using human stem cells applied to laboratory animals [13,46]. In this study, we opted for using sheep BMMSCs in some groups of rats, which were instilled at a pre-determined concentration directly in the composite at the transoperative moment, aiming to mimic clinical and surgical conditions. This action raises questions about the origin, methods of isolation, and cultivation of the mesenchymal stem cells with or without biomaterial as well as the timing of using these cells, which are highly divergent in studies with cell therapy in bone tissue engineering $[13,38,47,48]$. Despite the number of mesenchymal stem cells being in accordance with the recommendations of Brennan et al., it is believed that the cell activity may have been influenced because no culture was performed together with the composite for at least $24 \mathrm{~h}$ before the surgical procedure [28,49]. On the other hand, some authors believe that the cells should be placed next to the biomaterial at a certain time after the inflammatory phase caused by the surgery for the biomaterial implantation so that it can express its regenerative capacity and not only be immunomodulatory [47]. We understand that additional studies of cell viability after implantation are necessary, such as ex vivo immunofluorescence techniques [49]. However, no surface antibody markers for sheep stem cells validated for ex vivo use were available at the study time, which is a limitation also found in a previous study [14]. It is also known that biomaterial characteristics such as solubility, ions, and mechanical forces can influence the activity of mesenchymal stem cells after implantation [50].

\section{Conclusions}

The histological analysis showed that $\mathrm{CNCHN}$ had biocompatibility when applied to subcutaneous tissue and an osteoconductive potential in bone defects of rat calvaria. It is suggested that the way that the BM-MSCs were used or that CNCHN characteristics may have influenced their activity in enhancing bone regeneration. The application of the biomaterial to large animals on an experimental basis is necessary to evaluate its biological interaction before its application in clinical surgical cases.

Author Contributions: Conceptualization, G.M.M., A.L.V.Z. and A.M.G.P.; methodology, G.M.M., N.F.P., J.F., C.M.C.M., V.C.A.M. and D.T.F.; validation, G.M.M., J.F. and P.E.N.-S.; formal analysis, P.E.N.-S.; investigation, G.M.M.; resources, A.L.V.Z.; data curation, G.M.M. and N.F.P.; writingoriginal draft preparation, G.M.M.; writing-review and editing, G.M.M., J.F. and P.E.N.-S.; visualization, N.F.P. and D.T.F.; supervision, A.L.V.Z. and C.M.C.M.; project administration, G.M.M.; funding acquisition, A.L.V.Z. All authors have read and agreed to the published version of the manuscript.

Funding: This research was funded by FAPESP- Fundação de Amparo à Pesquisa do Estado de São Paulo, grant number 2016/21997-1.

Institutional Review Board Statement: The study was conducted according to the guidelines of the Declaration of Helsinki and approved by the Ethics Committee on the Use of Animals, School of Veterinary Medicine and Animal Science (FMVZ), University of São Paulo (USP), under protocol number 7100150715, on 15 July 2015.

Informed Consent Statement: Not applicable.

Data Availability Statement: The study data are available upon request from the corresponding author. 
Acknowledgments: The authors would like to expression their gratitude to the undergraduate students Jilma Maria Alemán Laporte, Marco Pereira, Rosana Thurler, Julio Ken Nagashima, and Grazieli Cristina Monteiro da Silva.

Conflicts of Interest: The authors declare no conflict of interest.

\section{References}

1. Oryan, A.; Alidadi, S.; Moshiri, A.; Maffulli, N. Bone regenerative medicine: Classic options, novel strategies, and future directions. J. Orthop. Surg. Res. 2014, 9, 18. [CrossRef]

2. Wang, W.; Yeung, K. Bone grafts and biomaterials substitutes for bone defect repair: A review. Bioact. Mater. 2017, 2, $224-247$. [CrossRef]

3. Lopez, M.J. Bone biology and fracture healing. In Equine Surgery, 5th ed.; Auer, J.A., Stick, J.A., Kümmerle, J.M., Prange, T., Eds.; Elsevier Saunders: St Louis, MI, USA, 2018; Volume 1, pp. 1255-1270.

4. Gaihre, B.; Jayasuriya, A.C. Comparative investigation of porous nano-hydroxyapatite/chitosan, nanozirconia/chitosan and novel nano-calcium zirconate/chitosan composite scaffolds for their potential applications in bone regeneration. Mat. Sci. Eng. C-Mater. 2018, 91, 330-339. [CrossRef]

5. Marcondes, G.M.; Nóbrega, F.S.; Correa, L.; Arana-Chavez, V.E.; Plepis, A.M.G.; Martins, V.C.A.; Zoppa, A.L.V. Avaliação da interação biológica entre compósito de quitosana, colágeno e hidroxiapatita e tecido ósseo ovino. Arq. Bras. Med. Vet. Zootec. 2016, 68, 1531-1538. [CrossRef]

6. Saravanan, S.; Leena, R.S.; Selvamurugan, N. Chitosan based biocomposite scaffolds for bone tissue engineering. Int. J. Biol. Macromol. 2016, 93, 1354-1365. [CrossRef] [PubMed]

7. Paretsis, N.F.; Arana-Chavez, V.E.; Correa, L.; Plepis, A.M.G.; Martins, V.C.A.; Cortopassi, S.R.G.; Zoppa, A.L.V. Avaliação histológica e histomorfométrica da regeneração óssea a partir da utilização de biomateriais em tíbias de ovinos. Pesq. Vet. Bras. 2017, 37, 1537-1544. [CrossRef]

8. Liu, X.; George, M.N.; Park, S.; Miller II, A.L.; Gaihre, B.; Li, L.; Walettzki, B.E.; Terzix, A.; Yaszemski, M.J.; Lu, L. 3D-printed scaffolds with carbon nanotubes for bone tissue engineering: Fast and homogeneous on-step functionalization. Acta Biomater. 2020, 111, 129-140. [CrossRef]

9. Patel, K.D.; Kim, T.; Mandakhbayar, N.; Singh, R.K.; Jang, J.; Lee, J.; Kim, H. Coating biopolymer nanofibers with carbon nanotubes accelerates tissue healing and bone regeneration through orchestrated cell-and tissue-regulatory responses. Acta Biomater. 2020, 108, 97-110. [CrossRef]

10. Gao, C.; Feng, P.; Peng, S.; Shuai, C. Carbon nanotube, graphene and boron nitride nanotube reinforced bioactive ceramics for bone repair. Acta Biomater. 2017, 61, 1-20. [CrossRef]

11. Eivazzadeh-Keihan, R.; Maleki, A.; de la Guardia, M.; Bani, M.S.; Chenab, K.K.; Pashazadeh-Panahi, P.; Baradaran, B.; Mokhtarzadeh, A.; Hamblin, M.R. Carbon based nanomaterials for tissue engineering of bone: Building new bone on small black scaffolds. J. Adv. Res. 2019, 18, 185-201. [CrossRef]

12. Tayton, E.; Purcell, M.; Smith, J.O.; Lanham, S.; Howdle, S.M.; Shakesheff, K.M.; Goodship, A.; Blunn, G.; Fowler, D.; Dunlop, D.G.; et al. The scale-up of a tissue engineered porous hydroxyapatite polymer composite scaffold for use in bone repair: An ovine femoral condyle defect study. J. Biomed. Mater. Res. A 2015, 103, 1346-1356. [CrossRef]

13. Blanco, J.F.; García-Briñon, J.; Benito-Garzón, L.; Pescador, D.; Muntión, S.; Sánchez-Guijo, F. Human bone marrow mesenchymal stromal cells promote bone regeneration in a xenogeneic rabbit model: A preclinical study. Stem Cells Int. 2018, $2018,7089484$. [CrossRef]

14. Kjærgaard, K.; Dreyer, C.H.; Ditzel, N.; Andreasen, C.M.; Chen, L.; Sheikh, S.P.; Overgaard, S.; Ding, M. Bone formation by sheep stem cells in an ectopic mouse model: Comparison of adipose and bone marrow derived cells and identification of donor-derived bone by antibody staining. Stem Cells Int. 2016, 2016, 3846971. [CrossRef]

15. Berner, A.; Henkel, J.; Woodruff, M.A.; Saifzadeh, S.; Kirby, G.; Zaiss, S.; Gohlke, J.; Reichert, J.C.; Nerlich, M.; Schuetz, M.A.; et al. Scaffold-cell bone engineering in a validated preclinical animal model: Precursors vs differentiated cell source. J. Tissue Eng. Reg. Med. 2017, 11, 2081-2089. [CrossRef] [PubMed]

16. Roseti, L.; Parisi, V.; Petretta, M.; Cavallo, C.; Desando, G.; Bartolotti, I.; Grigolo, B. Scaffolds for bone tissue engineering: State of the art and new perspectives. Mater. Sci. Eng. C Mater. Biol. Appl. 2017, 78, 1246-1262. [CrossRef]

17. Zhang, R.; Li, X.; Liu, Y.; Gao, X.; Zhu, T.; Lu, L. Acceleration of bone regeneration in critical-size defect using bmp-9-loaded nha/coli/mwcnts scaffolds seeded with bone marrow mesenchymal stem cells. Bio. Med. Res. Int. 2019, 2019, 7343957. [CrossRef]

18. Oréfice, R.L.; Pereira, M.M.; Mansur, H.S. Biomateriais: Fundamentos e Aplicações, 1st ed.; Reimpr. Cultura Médica, Guanabara Koogan: Rio de Janeiro, Brazil, 2012; pp. 212-538.

19. Li, Y.; Chen, S.K.; Li, L.; Qin, L.; Wang, X.L.; Lai, Y.X. Bone defect animal models for testing efficacy of bone substitute biomaterials. J. Orthop. Translat. 2015, 3, 95-104. [CrossRef]

20. Anderson, J.M. Biological responses to materials. Anuu. Rev. Mater. Res. 2001, 31, 81-110. [CrossRef]

21. Spicer, P.P.; Kretlow, J.D.; Young, S.; Jansen, J.A.; Kasper, F.K.; Mikos, A.G. Evaluation of bone regeneration using the rat critical size calvarial defect. Nat. Protoc. 2012, 7, 1918-1929. [CrossRef] 
22. Ferreira, L.B.; Bradaschia-Correa, V.; Moreira, M.M.; Marques, N.D.; Arana-Chavez, V.E. Evaluation of bone repair of critical size defects treated with simvastatin-loaded poly(lactic-co-glycolic acid) microspheres in rat calvaria. J. Biomater. Appl. 2015, 29, 965-976. [CrossRef]

23. Wang, J.; Hao, S.; Luo, T.; Zhou, T.; Yang, X.; Wang, B. Keratose/poly (vinyl alcohol) blended nanofibers: Fabrication and biocompatibility assessment. Mater. Sci. Eng. C Mater. Biol. Appl. 2017, 72, 212-219. [CrossRef]

24. Hernandes, L.; Ramos, A.L.; Micheletti, K.R.; Santi, A.P.; Cuoghi, O.A.; Salazar, M. Densitometry, radiography, and histological assessment of collagen as methods to evaluate femoral bones in an experimental model of osteoporosis. Osteoporos. Int. 2012, 23, 467-473. [CrossRef]

25. Yaneva-Deliverska, M.; Deliversky, J.; Lyapina, M. Biocompatibility of biomedical devices-legal regulations in the Europe union. J. IMAB 2015, 21, 705-708. [CrossRef]

26. Khorramirouz, R.; Go, J.L.; Noble, C.; Jana, S.; Maxson, E.; Lerman, A.; Young, M.D. A novel surgical technique for a rat subcutaneous implantation of a tissue engineered scaffold. Acta Histochem. 2018, 120, 282-291. [CrossRef]

27. Paretsis, N.F.; Gonçalves, V.J.; Hazarbassanov, G.T.Q.; Marcondes, G.M.; Plepis, A.M.G.; Arana-Chavez, V.E.; Zoppa, A.L.V. In Vitro evaluation of hydroxyapatite, chitosan and carbon nanotube composite biomaterial for support bone healing. Braz. J. Vet. Res. Anim. Sci. 2021, 58. in press. [CrossRef]

28. Smith, J.O.; Tayton, E.R.; Khan, F.; Aarvold, A.; Cook, R.B.; Goodship, A.; Bradley, M.; Oreffo, R.O. Large animal in vivo evaluation of a binary blend polymer scaffold for skeletal tissue-engineering strategies; translational issues. J. Tissue Eng. Regen. Med. 2017, 11, 1065-1076. [CrossRef]

29. Feitosa, M.L.; Fadel, L.; Beltrão-Braga, P.C.; Wenceslau, C.V.; Kerkis, I.; Kerkis, A.; Birgel Júnior, E.H.; Martins, J.F.; Martins, D.; Miglino, M.A.; et al. Successful transplant of mesenchymal stem cells in induced osteonecrosis of the ovine femoral head: Preliminary results. Acta Cir. Bras. 2010, 25, 416-422. [CrossRef]

30. Reichert, J.C.; Gohlke, J.; Friis, T.E.; Quent, V.M.; Hutmacher, D.W. Mesodermal and neural crest derived ovine tibial and mandibular osteoblasts display distinct molecular differences. Gene 2013, 525, 99-106. [CrossRef]

31. Barberini, D.J.; Freitas, N.P.; Magnoni, M.S.; Maia, L.; Listoni, A.J.; Heckler, M.C.; Sudano, M.J.; Golim, M.A.; da Cruz LandimAlvarenga, F.; Amorim, R.M. Equine mesenchymal stem cells from bone marrow, adipose tissue and umbilical cord: Immunophenotypic characterization and differentiation potential. Stem Cell Res. Ther. 2014, 5, 25. [CrossRef]

32. Fülber, J.; Maria, D.A.; da Silva, L.C.; Massoco, C.O.; Agreste, F.; Baccarin, R.Y.A. Comparative study of equine mesenchymal stem cells from healthy and injured synovial tissues: An in vitro assessment. Stem Cell Res. Ther. 2016, 7, 35. [CrossRef]

33. Burim, R.A.; Sendyk, D.I.; Hernandes, L.S.; de Souza, D.F.; Correa, L.; Deboni, M.C. Repair of critical calvarias defects with systemic epimedium sagittatum extract. J. Craniofac. Surg. 2016, 27, 799-804. [CrossRef]

34. Nóbrega, F.S.; Selim, M.B.; Arana-Chavez, V.E.; Correa, L.; Ferreira, M.P.; Zoppa, A.L.V. Histologic and immunohistochemical evaluation of biocompatibility of castor oil polyurethane polymer with calcium carbonate in equine bone tissue. Am. J. Vet. Res. 2017, 78, 1210-1214. [CrossRef]

35. Oliveira, H.L.; Da Rosa, W.; Cuevas-Suárez, C.E.; Carreño, N.; da Silva, A.F.; Guim, T.N.; Dellagostin, O.A.; Piva, E. Histological evaluation of bone repair with hydroxyapatite: A systematic review. Calcif. Tissue Int. 2017, 101, 341-354. [CrossRef] [PubMed]

36. Türk, S.; Altınsoy, I.; Çelebi, E.G.; Ipek, M.; Özacar, M.; Bindal, C. 3D porous collagen/functionalized multiwalled carbon nanotube/chitosan/hydroxyapatite composite scaffolds for bone tissue engineering. Mater. Sci. Eng. C Mater. Biol. Appl. 2018, 92, 757-768. [CrossRef] [PubMed]

37. Gomes, P.S.; Fernandes, M.H. Rodent models in bone-related research: The relevance of calvarial defects in the assessment of bone regeneration strategies. Lab. Anim. 2011, 45, 14-24. [CrossRef] [PubMed]

38. Muschler, G.F.; Raut, V.P.; Patterson, T.E.; Wenke, J.C.; Hollinger, J.O. The design and use of animal models for translational research in bone tissue engineering and regenerative medicine. Tissue Eng. Part B Rev. 2010, 16, 123-145. [CrossRef]

39. Kim, J.; Kim, H. Rat defect models for bone grafts and tissue engineered bone constructs. Tissue Eng. Regen. Med. 2013, 10, 310-316. [CrossRef]

40. McGovern, J.A.; Griffin, M.; Hutmacher, D.W. Animal models for bone tissue engineering and modelling disease. Dis. Model. Mech. 2018, 11, 1-14. [CrossRef]

41. Auer, J.A.; Goodship, A.; Arnoczky, S.; Pearce, S.; Price, J.; Claes, L.; von Rechenberg, B.; Hofmann-Amtenbrinck, M.; Schneider, E.; Müller-Terpitz, R.; et al. Refining animal models in fracture research: Seeking consensus in optimising both animal welfare and scientific validity for appropriate biomedical use. BMC Musculoskelet. Disord. 2007, 8, 72. [CrossRef]

42. Peric, M.; Dumic-Cule, I.; Grcevic, D.; Matijasic, M.; Verbanac, D.; Paul, R.; Grgurevic, L.; Trkulja, V.; Bagi, C.M.; Vukicevic, S. The rational use of animal models in the evaluation of novel bone regenerative therapies. Bone 2015, 70, 73-86. [CrossRef]

43. Fonseca, T.S.; da Silva, G.F.; Tanomaru-Filho, M.; Sasso-Cerri, E.; Guerreiro-Tanomaru, J.M.; Cerri, P.S. In vivo evaluation of the inflammatory response and IL-6 immunoexpression promoted by Biodentine and MTA Angelus. Int. Endod. J. 2016, 49, 145-153. [CrossRef]

44. Amaral, M.B.; Viana, R.B.; Viana, K.B.; Diagone, C.A.; Denis, A.B.; Plepis, A.M.G. In vitro and in vivo response of composites based on chitosan, hydroxyapatite and collagen. Acta Scient. Tech. 2019, 42, e41102. [CrossRef]

45. Sheikh, Z.; Brooks, P.J.; Barzilay, O.; Fine, N.; Glogauer, M. Macrophages, foreign body giant cells and their response to implantable biomaterials. Materials 2015, 8, 5671-5701. [CrossRef] [PubMed] 
46. Brennan, M.A.; Renaud, A.; Amiaud, J.; Rojewski, M.T.; Schrezenmeier, H.; Heymann, D.; Trichet, V.; Layrolle, P. Pre-clinical studies of bone regeneration with human bone marrow stromal cells and biphasic calcium phosphate. Stem Cells Res. Ther. 2014, 5, 114. [CrossRef]

47. Berner, A.; Henkel, J.; Woodruff, M.A.; Steck, R.; Nerlich, M.; Schuetz, M.A.; Hutmacher, D.W. Delayed minimally invasive injection of allogenic bone marrow stromal cell sheets regenerates large bone defects in an ovine preclinical animal model. Stem Cells Transl. Med. 2015, 4, 503-512. [CrossRef] [PubMed]

48. Yousefi, A.M.; James, P.F.; Akbarzadeh, R.; Subramanian, A.; Flavin, C.; Oudadesse, H. Prospect of stem cells in bone tissue engineering: A review. Stem Cells Int. 2016, 2016, 6180487. [CrossRef]

49. Zhang, W.; Zhu, C.; Ye, D.; Xu, L.; Zhang, X.; Wu, Q.; Zhang, X.; Kaplan, D.L.; Jiang, X. Porous silk scaffolds for delivery of growth factors and stem cells to enhance bone regeneration. PLOS ONE 2014, 9, e102371. [CrossRef]

50. Osugi, M.; Katagiri, W.; Yoshimi, R.; Inukai, T.; Hibi, H.; Ueda, M. Conditioned media from mesenchymal stem cells enhanced bone regeneration in rat calvarial bone defects. Tissue Eng. Part A 2012, 18, 1479-1489. [CrossRef] 